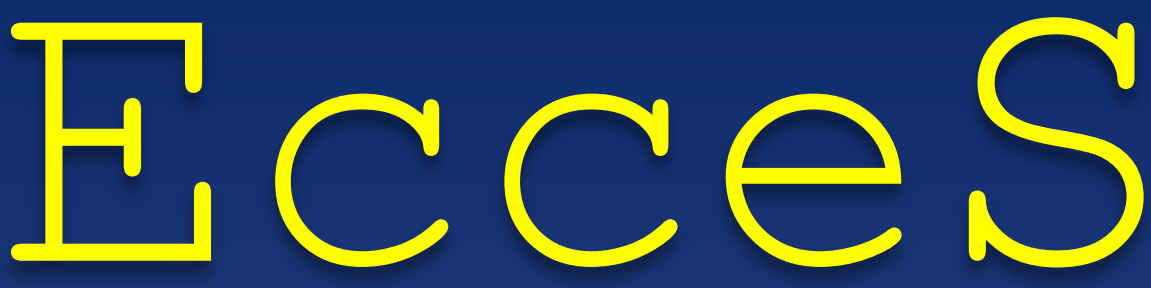

Economics, Social, and Development Studies

POSISI PENDUDUK KOTA MAKASSAR DALAM MENUNJANG

PEMBANGUNAN EKONOMI

Abdul Rahman dan Nur Rahmi Hamzah

EFISIENSI BELANJA PEMERINTAH DI SEKTOR PENDIDIKAN DAN KESEHATAN

DI PROVINSI SULAWESI SELATAN

Rapiuddin dan Bahrul Ulum Rusydi

STRUKTUR EKONOMI DAN POLA PEMBANGUNAN DAERAH

DI KAWASAN MAMMINASATA

Husni Mubarak dan Hasbiullah

PENGARUH PENGELUARAN PEMERINTAH DAN UPAH MINIMUM REGIONAL (UMR) TERHADAP TINGKAT PARTISIPASI ANGKATAN KERJA DI KOTA MAKASSAR

Ikhwan dan Siradjuddin

PENGARUH TENAGA KERJA DAN PENGELUARAN PEMERINTAH TERHADAP PERTUMBUHAN EKONOMI KOTA MAKASSAR

Irmayanti dan Aulia Rahman Bato

FAKTOR-FAKTOR YANG MEMENGARUHI PRODUKSI JAGUNG DI DESA TANAH TOWA KECAMATAN KAJANG KABUPATEN BULUKUMBA

Kamaluddin dan Andi Faisal Anwar

ANALISIS PENENTUAN SEKTOR UNGGULAN DAN PERUBAHAN STRUKTUR EKONOMI KABUPATEN JENEPONTO TAHUN 2011-2015

Syaripuddin dan Abdul Wahab 


\section{Ecces}

Economics, Social, and Development Studies

VOLUME 4 NOMOR 1 JUNI 2017

POSISI PENDUDUK KOTA MAKASSAR DALAM MENUNJANG

PEMBANGUNAN EKONOMI

Abdul Rahman dan Nur Rahmi Hamzah

EFISIENSI BELANJA PEMERINTAH DI SEKTOR PENDIDIKAN DAN KESEHATAN DI PROVINSI SULAWESI SELATAN

Rapiuddin dan Bahrul Ulum Rusydi

STRUKTUR EKONOMI DAN POLA PEMBANGUNAN DAERAH DI KAWASAN MAMMINASATA

Husni Mubarak dan Hasbiullah

PENGARUH PENGELUARAN PEMERINTAH DAN

UPAH MINIMUM REGIONAL (UMR) TERHADAP TINGKAT PARTISIPASI

ANGKATAN KERJA DI KOTA MAKASSAR

Ikhwan dan Siradjuddin

PENGARUH TENAGA KERJA DAN PENGELUARAN PEMERINTAH TERHADAP PERTUMBUHAN EKONOMI KOTA MAKASSAR

Irmayanti dan Aulia Rahman Bato

FAKTOR-FAKTOR YANG MEMENGARUHI PRODUKSI JAGUNG DI DESA TANAH TOWA KECAMATAN KAJANG KABUPATEN BULUKUMBA

Kamaluddin dan Andi Faisal Anwar

ANALISIS PENENTUAN SEKTOR UNGGULAN DAN PERUBAHAN STRUKTUR EKONOMI KABUPATEN JENEPONTO TAHUN 2011-2015

Syaripuddin dan Abdul Wahab 


\title{
EFISIENSI BELANJA PEMERINTAH DI SEKTOR PENDIDIKAN DAN KESEHATAN DI PROVINSI SULAWESI SELATAN
}

\author{
Rapiuddin ${ }^{1}$ \\ Bahrul Ulum Rusydi ${ }^{2}$
}

\begin{abstract}
ABSTRAK
Tujuan dalam penelitian ini adalah menganlisis efisiensi teknis anggaran bidang pendidikan dan bidang kesehatan di 24 kabupaten/kota di Provinsi Sulawesi Selatan. Penelitian dengan menggunakan analisis efisiensi ini, dapat juga menjadi salah satu cara untuk mengetahui sumber ketidakefisienan daerah Kabupaten/kota di Provinsi Sulawesi Selatan serta memberi masukan kebijakan bagi pemerintah Kabupaten/kota yang belum efisien agar daerah tersebut dapat menjadi efisien.

Metode analisis yang digunakan dalam penelitian ini adalah Data Envelopment Analysis (DEA) dengan asumsi Variabel Return to Scale (VRS). Analisis DEA di desain secara spesifik untuk mengukur efisiensi relative dalam kondisi banyak input maupun banyak output. Penggunaan biaya perkapita pada bidang pendidikan dan bidang kesehatan sebagai variabel input, penggunaan rasio guru per murid (RGM), rasio sekolah per murid (RSM), rasio jumlah dokter dan jumlah puskesmas sebagai variabel intermediate output serta angka melek huruf (AMH), angka partisipasi sekolah (APS), angka kematian bayi (AKB) dan angka harapan hidup $(\mathrm{AHH})$ sebagai variabel outcome.

Hasil penelitian ini menunjukkan bahwa secara umum sebagian besar daerah kabupaten/kota di Provinsi Sulawesi Selatan masih belum efisien dalam teknis biaya maupun teknis sistem. Hal ini mengindikasikan masih terjadinya pemborosan dalam belanja pendidikan dan belanja kesehatan yang cukup besar namun tidak diikuti dengan layanan dan fasilitas pendidikan dan kesehatan serta belum ada upaya perbaikan sistem untuk meningkatatkan derajat pendidikan dan kesehatan masyarakat.
\end{abstract}

Kata kunci: Efisiensi, Belanja Pendidikan dan kesehatan, Data Envelopment Analysis, Efisiensi teknis biaya, Efisiensi teknis sistem

\section{PENDAHULUAN}

Belanja yang efisien diyakini dapat mendorong peningkatan kesejahteraan masyarakat secara lebih luas. Jika penggunaannya hemat dan tepat sasaran dikatakan efisiensinya tinggi. Jika terjadi yang sebaliknya, efisiensinya berarti rendah. Efisiensi dapat terjadi ketika dana yang tersedia secara cukup dapat memberikan pelayanan yang optimal sehingga mampu mencapai derajat

\footnotetext{
1 Universitas Islam Negeri Alauddin Makassar

2 Universitas Islam Negeri Alauddin Makassar, bahrul.rusydi@uin-alauddin.ac.id
} 
masyarakat yang baik. Oleh karena itu, belanja yang efisien merupakan isu penting dalam kebijakan sektor publik terutama belanja di bidang pendidikan dan kesehatan.

Data dari Direktorat Jenderal Perimbangan menunjukkan bahwa pada tahun 2013-2014, alokasi belanja kesehatan dan pendidikan Provinsi Sulawesi Selatan terus mengalami peningkatan yang signifikan besarannya. Proporsi anggaran belanja sektor kesehatan di Provinsi Sulawesi Selatan pada tahun 2013 sebesar Rp340,656 Milyar dan untuk sektor pendidikan sebesar Rp119,067 Milyar. Pada tahun 2014 proporsi anggaran sektor kesehatan terjadi kenaikan sebesar Rp395,938 Milyar begitu pula dengan sektor pendidikan mengalami kenaikan sebesar Rp228,154 Milyar.

Secara keseluruhan tingkat pendidikan di Sulawesi Selatan belum berkembang. Angka Partisipasi Sekolah (APS) usia 7-12 tahun dan 13-15 tahun (pendidikan dasar) tahun 2013 antarkota dan kabupaten di Provinsi Sulawesi Selatan tidak merata. Rata-rata APS Provinsi Sulawesi Selatan tahun 2013 sebesar 98,21\% untuk usia 7-12 tahun dan 89,55\% untuk usia 13-15 tahun. Kabupaten di Provinsi Sulawesi Selatan dengan APS terendah meliputi Kabupaten Sinderang Rappang (77,43\%), Bone (83,95\%), dan Maros (85,4\%). Semakin tinggi jenjang pendidikan di Sulawesi Selatan, semakin rendah angka partisipasi sekolahnya. Hal ini mengambarkan masih kurangnya partisipasi masyarakat untuk melanjutkan pendidikan ke jenjang yang lebih tinggi. Rata-rata penduduk Sulawesi Selatan mengikuti pendidikan hanya sampai kelas tingkat SMP. ${ }^{3}$

Tingkat kesehatan masyarakat Sulawesi Selatan belum menunjukkan hasil yang baik apabila dilihat dari indikator kesehatan, seperti angka kematian ibu, angka kematian bayi, dan balita, serta gizi buruk. Angka kematian bayi di Sulawesi Selatan pada tahun 2012 sebanyak 25 kematian per 1000 kelahiran baru, sedangkan angka nasional menunjukkan 34 kematian per 1000 kelahiran baru. Angka ini mengalami penurunan bila dibandingkan dengan kondisi pada tahun 2007, angka kematian bayi Sulawesi Selatan 41 kematian per 1000 kelahiran hidup. Sementara itu, angka kematian balita 37 kematian per 1000 kelahiran hidup atau menurun dari kondisi tahun 2007 sebesar 66 kematian per 1000 kelahiran 
hidup. Tingginya nilai AKB suatu wilayah menunjukkan kesehatan di wilayah tersebut rendah. ${ }^{4}$

Pendidikan dan kesehatan mempunyai peranan yang penting dalam peningkatan kualitas sumber daya manusia (SDM). Pendidikan mempengaruhi secara penuh pertumbuhan ekonomi suatu bangsa dan kualitas pembangunan manusia (IPM). Hal ini bukan saja karena pendidikan akan berpengaruh terhadap produktifitas, tetapi juga akan berpengaruh terhadapap fertilitas masyarakat. Kesehatan merupakan inti dari kesejahteraan, dan pendidikan adalah hal pokok untuk mencapai kehidupan yang layak. Oleh karena itu, pemerintah Provinsi Sulawesi Selatan harus mampu meningkatkan aksesibilitas dan kualitas pelayanan pendidikan dan kesehatan. Dari belanja pemerintah daerah Provinsi Sulawesi Selatan yang telah dilakukan apakah sudah dikatakan efisiensi atau inefisiensi, hal itu yang menjadi latar belakang penelitian ini.

\section{TINJAUAN PUSTAKA}

\section{Teori Pengeluaran Pemerintah}

Pengeluaran pemerintah mencerminkan kebijakan pemerintah. Apabila pemerintah telah menetapkan suatu kebijakan untuk membeli barang dan jasa, pengeluaran pemerintah "mencerminkan biaya yang harus dikeluarkan oleh pemerintah untuk melaksanakan kebijakan tersebut". ${ }^{5}$

Adolf Wagner menyatakan bahwa pengeluaran pemerintah dan kegiatan pemerintah semakin lama semakin meningkat. Tendensi ini oleh Wagner disebut dengan hokum selalu meningkatnya peranan pemerintah. Inti teorinya yaitu makin meningkatnya peran pemerintah dalam kegiatan dan kehidupan ekonomi masyarakat sebagai suatu keseluruhan. Wagner menyatakan dalam suatu perekonomian apabila pendapatan per kapita meningkat maka secara relatif pengeluaran pemerintah pun akan meningkat terutama disebabkan karena pemerintah harus mengatur hubungan yang timbul dalam masyarakat, hukum, pendidikan, rekreasi, kebudayaan, dan sebagainya.

\footnotetext{
${ }^{4} /$ bid

${ }^{5}$ Basri, Zainal Yusman, Subri Mulyadi, Keuangan Negara dan Analisis Kebijakan Utang Luar Negeri (Jakarta: PT Raja Grafindo), h. 49
} 
Berkaitan dengan hukum Wagner, dapat dilihat beberapa penyebab semakin meningkatnya pengeluaran pemerintah, yakni meningkatnya fungsi pertahanan keamanan dan ketertiban, meningkatnya fungsi kesejahteraan, meningkatnya fungsi perbankan dan meningkatnya fungsi pembangunan. Hukum Wagner dapat diformulasikan sebagai berikut :

$$
\frac{\mathrm{PP}_{\mathrm{k}} \mathrm{P}}{\mathrm{PPK}_{1}}<\frac{\mathrm{P}_{\mathrm{k}} \mathrm{PP}_{\mathrm{n}}}{\mathrm{PPK}_{2}}<. .<\frac{\mathrm{P}_{\mathrm{k}} \mathrm{PP}_{\mathrm{n}}}{\mathrm{PPK}_{\mathrm{n}}}
$$

Dimana

PPkP : Pengeluaran pemerintah per kapita

PPK : Pendapatan per kapita, yaitu GDP/ jumlah penduduk

n : Jangka waktu tahun

Gambar 1. Kurva Perkembangan Pengeluaran Pemerintah

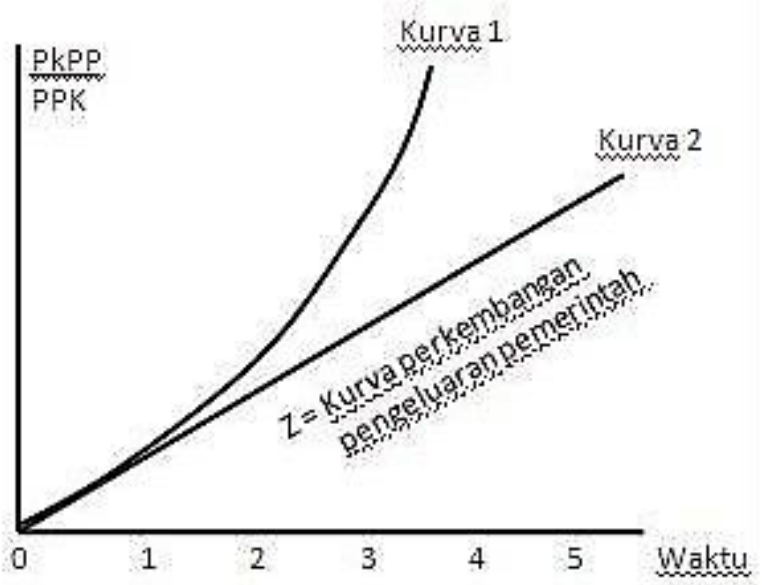

Sumber: Mangkoesoebroto, 1998

Teori Wagner mendasarkan pandanganya pada suatu teori yang disebut organic theory of state yaitu teori organis yang mengangap pemerintah sebagai individu yang bebas bertindak terlepas dengan masyarakat lain. Kurva di atas menunjukkan secara relatif peranan pemerintah semakin meningkat.

\section{Konsep Efisiensi}

Efisiensi dapat dapat dilihat dari 2 segi, pertama, hasil yang telah dicapai, dan kedua adalah usaha yang telah dilakukan. Suatu kegiatan dapat disebut efisien jika usaha yang telah dilakukan, memberikan output yang maksimum, baik dari jumlah maupun kualitas. Suatu kegiatan dapat dapat dikatakan efisien jika 
dengan usaha minimum dapat mencapai output tertentu. Usaha yang dimaksud mencakup material, pikiran, tenaga jasmani, ruang dan waktu. Jadi istilah efisiensi mempunyai pengertian yang sudah pasti, yaitu "menunjukkan adanya perbandingan antara keluaran dan masukan". ${ }^{6}$

Ada tiga faktor yang menyebabkan efisiensi, yaitu apabila dengan input yang sama menghasilkan output yang lebih besar, dengan input yang lebih kecil menghasilkan output yang sama, dan dengan output yang lebih besar menghasilkan output yang lebih besar. Jika pengertian efisiensi dijelaskan dengan pengertian input-output maka efisiensi merupakan rasio antara output dengan input atau dinyatakan dengan rumus sebagai berikut.

$$
E=0 / I
$$

Keterangan :

$$
\begin{aligned}
E & =\text { Efisiensi } \\
O & =\text { Output } \\
I & =\text { Input }
\end{aligned}
$$

Efisiensi merupakan hasil perbandingan antara output fisik dan input fisik. Semakin tinggi rasio output terhadap input maka semakin tinggi tingkat efisiensi yang dicapai. Efisiensi juga dapat dijelaskan sebagai pencapain output maksimum dari penggunaan sumber daya tertentu. Jika output yang dihasilkan lebih besar dari pada sumber daya yang digunakan maka semakin tinggi pula tingkat efisiensi yang dicapai.

\section{Kerangka Pemikiran Teoritis}

Berdasarkan pada hasil telaah teoritis dan pengamatan empiris sederhana, maka dapat digambarkan kerangka pemikiran dari penelitian ini sebagai berikut: 


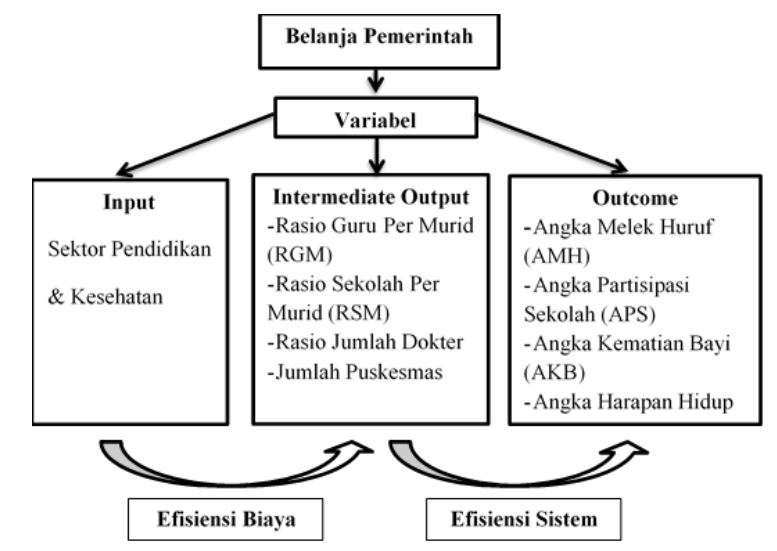

\section{METODE PENELITIAN}

\section{Variabel Penelitian}

Dalam menganalisis tingkat efisiensi belanja pendidikan dan kesehatan pemerintah daerah di Provinsi Sulawesi Selatan, penelitian ini menggunakan tiga jenis variabel yaitu variabel input yaitu belanja pemerintah di sektor pendidikan dan kesehatan, variable output intermediate yang terdiri dari Rasio Guru per Murid (RGM), Rasio Guru per Sekolah (RMS), rasio jumlah dokter, rasio jumlah puskesmas, dan variabel outcome yaitu Angka Melek Huruf (AMH), Angka Partisipasi Sekolah (APS), Angka Kematian Bayi (AKB), Angka Harapan Hidup $(\mathrm{AHH})$.

\section{Model Analisis}

Data Envelopment Analysis (DEA) adalah sebuah metode optimasi program matematika yang dipergunakan untuk mengukur efisiensi teknis suatu unit Decision Making Unit (DMU) dan membandingkan secara relative terhadap DMU lain". ${ }^{7}$ DEA merupakan suatu teknik pemprograman matematis yang digunakan untuk mengevaluasi efisiensi relatif dari sebuah kumpulan unit-unit pembuat keputusan (DMU) dalam mengelolah sumber daya (input) sehingga menjadi hasil (output) di mana hubungan bentuk fungsi dari input ke output tidak diketahui.

Sedangkan menurut Cooper DEA menggunakan teknis program matematis yang dapat menangani variabel dan batasan yang banyak, dan tidak membatasi input dan output yang akan dipilih kerena teknis yang dipakai dapat

${ }^{7}$ Charnes, A, WW Cooper and E Rhodes, Measuring the efficiency of Decision Maing Units. European Journal of Operational Research 2, (North : Holland Publising Company, 1978), h. 429444 
mengatasinya. ${ }^{8}$ DMU adalah organisasi-organisasi atau entitas-entitas yang akan diikur efisiensinya secara relatif terhadap sekelompok entitas lainnya yang homogen. Homogen berarti input dan output dari DMU yang akan diveluasi harus sama/sejenis. DMU dapat berupa entitas komersial maupun publik, seperti bank komersial atau pemerintah, sekolah negeri atau swasta, ruamah sakit dan sebagainya.

Metode analisis yang digunakan adalah metode non parametric dengan metode Data Envelopment Analysis (DEA). DEA merupakan prosedur yang didesaian relatif suatu unit kegiatan ekonomi (UKE) yang menggunakan banyak input dan banyak output (multi-input multi-output) di mana penggabungan input dan output tersebut tidak dapat dilakukan. Dalam metode penelitian ini melibatkan input pendidikan dan kesehatan di Sulawesi Selatan sedangkan output intermediate yaitu rasio guru/murid, rasio sekolah murid, rasio jumlah dokter dan jumlah puskesmas dan menggunakan outcome yang meliputi angka melek huruf angka partisipasi sekolah, angka kematian bayi dan angka harapan hidup.

Efisiensi yang diukur oleh analisis DEA memiliki karakter berbeda dengan konsep efisiensi pada umumnya. Pertama, efisiensi yang diukur adalah bersifat teknis, bukan ekonomis, artinya, analisis DEA hanya memperhitungkan nilai absolut dari suatu variabel. Satuan dasar pengukuran yang mencerminkan nilai ekonomis dari tiap-tiap variabel seperti harga, berat, panjang, isi dan lainnya tidak dipertimbangkan. Oleh karenanya dimungkinkan suatu pola perhitungan kombinasi berbagai variabel dengan satuan yang berbeda-beda. Kedua, nilai efisiensi uang dihasilkan bersifat relative, atau hanya berlaku dalam sekumpulan UKE yang diperbandingkan tersebut. ${ }^{9}$

\section{HASIL DAN PEMBAHASAN}

Nilai efisiensi teknis biaya pendidikan pemerintah daerah di provinsi Sulawesi Selatan diperoleh dengan menggunakan variabel input berupa nominal jumlah belanja pendidikan yang dikeluarkan masing-masing pemerintah daerah Kabupaten/Kota. Adapun variabel output yang digunakan untuk menghitung nilai

${ }^{8}$ William Cooper, Lawrence M. Seiford and Joe Zhu. Chapter 1 : Data Envelopment Analysis : History, Model and Interpretations. http://users.wpi.edu/ izhu/dea/hbchapter1.pdf

${ }^{9}$ Nugroho Purwantoro, Efektitas Kinerja Pelabuhan dengan data Envelopment Analysis (DEA), Manajemen Usahawan Indonesia No. 05,Th XXXIII, 2004. 
efisiensi teknis adalah variabel output intermediate berupa indikator yang tersedia adalah rasio guru per murid dan rasio murid per sekolah.

Asumsi yang digunakan adalah bahwa besarnya input belanja pendidikan yang dikeluarkan pemerintah daerah mampu menghasilkan jumlah output fasilitas dan layanan pendidikan dengan besaran yang tidak sama. Perhitungan efisiensi teknis biaya ini menggunakan asusmsi Variabel Ruturn to Scale (VRTS) dan model orientasi input (input oriented).

Tabel 1. Nilai Efisiensi Teknis Biaya Pendidikan Per Kabupaten/Kota di Provinsi Sulawesi Selatan Tahun 2012-2014

\begin{tabular}{|c|c|c|c|c|}
\hline \multirow{2}{*}{ Kabupaten/Kota } & \multicolumn{3}{|c|}{ Efisiensi } & \multirow[t]{2}{*}{ Rata-Rata Efisiensi } \\
\hline & 2012 & 2013 & 2014 & \\
\hline Selayar & $100,00 \%$ & $100,00 \%$ & $100,00 \%$ & $100 \%$ \\
\hline Bulukumba & $40.07 \%$ & $37.34 \%$ & $35.94 \%$ & $37.78 \%$ \\
\hline Bantaeng & $92.62 \%$ & $62.69 \%$ & $100,00 \%$ & $85.10 \%$ \\
\hline Jeneponto & $62.74 \%$ & $45.93 \%$ & $50.25 \%$ & $52.97 \%$ \\
\hline Takalar & $44.95 \%$ & $51.20 \%$ & $56.44 \%$ & $50.86 \%$ \\
\hline Gowa & $36.38 \%$ & $35.63 \%$ & $36.36 \%$ & $36.12 \%$ \\
\hline Sinjai & $49.29 \%$ & $48.80 \%$ & $100,00 \%$ & $66.03 \%$ \\
\hline Maros & $62.38 \%$ & $39.17 \%$ & $45.89 \%$ & $49.15 \%$ \\
\hline Pangkep & $41.24 \%$ & $38.43 \%$ & $40.74 \%$ & $40.14 \%$ \\
\hline Barru & $59.17 \%$ & $54.29 \%$ & $54.61 \%$ & $56.02 \%$ \\
\hline Bone & $29.81 \%$ & $31.11 \%$ & $34.25 \%$ & $31.72 \%$ \\
\hline Soppeng & $46.58 \%$ & $45.48 \%$ & $40.62 \%$ & $44.23 \%$ \\
\hline Wajo & $48.94 \%$ & $47.94 \%$ & $48.23 \%$ & $48.37 \%$ \\
\hline Sidrap & $50.27 \%$ & $57.52 \%$ & $63.36 \%$ & $57.05 \%$ \\
\hline Pinrang & $51.66 \%$ & $51.50 \%$ & $50.19 \%$ & $51.12 \%$ \\
\hline Enrekang & $71.94 \%$ & $73.00 \%$ & $50.78 \%$ & $65.24 \%$ \\
\hline Luwu & $61.21 \%$ & $49.10 \%$ & $46.48 \%$ & $52.26 \%$ \\
\hline Tana Toraja & $72.93 \%$ & $78.79 \%$ & $84.20 \%$ & $78.64 \%$ \\
\hline Luwu Utara & $59.24 \%$ & $61.94 \%$ & $62.05 \%$ & $61.08 \%$ \\
\hline Luwu Timur & $76.81 \%$ & $86.00 \%$ & $84.47 \%$ & $82.43 \%$ \\
\hline Toraja Utara & $75.59 \%$ & $85.18 \%$ & $85.15 \%$ & $81.97 \%$ \\
\hline Makassar & $24.62 \%$ & $25.80 \%$ & $28.66 \%$ & $26.36 \%$ \\
\hline Pare-Pare & $100,00 \%$ & $100,00 \%$ & $78.69 \%$ & $93.00 \%$ \\
\hline Palopo & $100,00 \%$ & $100,00 \%$ & $100,00 \%$ & $100 \%$ \\
\hline Rata-rata Provinsi & $61.00 \%$ & $59.00 \%$ & $62.00 \%$ & \\
\hline
\end{tabular}

Sumber : Hasil Perhitungan dengan DEA-VRS-Input Orientation, diolah 
Tabel 1 menunjukkan hasil analisis efisiensi teknis biaya pendidikan pemerintah daerah di Provinsi Sulawesi Selatan dengan menggunakan DEA dalam kurun waktu 2012-2014. Adapun pembahasannya adalah sebagai berikut :

- Pada tahun 2012, hasil perhitungan nilai efisiensi teknis biaya pendidikan di 24 Kabupaten/Kota menunjukkan bahwa hanya terdapat 3 Kabupaten/Kota yang mencapai nilai efisiensi 100\%, yaitu Kabupaten Selayar, Kota Pare-Pare dan Kota Palopo.

- Pada tahun 2013 jumlah Kabupaten/Kota yang mampu mencapai skor efesiensi $100 \%$ tidak mengalami perubahan tetap berada pada kondisi tahun sebelumnya. Kota Makassar dengan rata-rata belanja paling tinggi jauh di atas lainnya yang mencapai Rp. 698.240.000,00 namun hanya memiliki skor efisiensi $25.80 \%$ paling rendah dan di bawah $50 \%$. Hal ini sejalan dengan pendapat Greert dan Andreas bahwa pengeluaran relatif besar pada sektor pendidikan tidak selalu menghasilkan capain yang paling efisien.

- Pada tahun 2014 kondisi pencapai efisiensi teknis biaya pendidikan hanya 4 Kabupaten/Kota yang mencapai efisiensi $100 \%$ yaitu hanya Kabupaten Selayar, Kabupaten Bantaeng, Kabupaten Sinjai dan Kota Palopo. Hal ini menunjukkan bahwa secara teknis biaya belum ada upaya yang secara signifikan telah dilakukan pemerintah Kabupaten/Kota di Provinsi Sulawesi Selatan selama tiga tahun penelitian.

- Berdasarkan hasil perhitungan selama periode penelitian menunjukkan bahwa pencapain nilai efisiensi di seluruh Kabupaten/Kota hanya sebanyak 3 Kabupaten/Kota dari seluruh objek penelitian yang telah efisien $100 \%$ dalam menggunakan belanja pendidikan daerahnya secara konsisten selama periode penelitian.

\section{Efisiensi Teknis Sistem Pendidikan}

Perhitungan efisiensi teknis sistem ini menggunakan asumsi Variabel Return to Scale (VRS) dengan orientasi output (output oriented). Berdasarkan hasil Tabel 2 dapat dijelaskan hasil empiris tentang efisiensi teknis sistem belanja pendidikan pemerintah daerah di Provinsi Sulawesi Selatan sebagai berikut :

- Pada tahun 2012, hasil perhitungan nilai efisiensi teknis sistem belanja sektor pendidikan di 24 Kabupaten/Kota menunjukkan bahwa terdapat 10 
Kabupaten/Kota yang mencapai tingkat efesiensi dengan nilai efisiensi mencapai 100\%. Daerah Kabupaten/Kota yang meraih efisiensi yaitu Kabupaten Selayar, Kabupaten Jeneponto, Kabupaten Pangkep, Kabupaten Sidrap, Kabupaten Pinrang, Kabupaten Enrekang, Kabupaten Toraja Utara, Kota Makassar, Kota Pare-Pare dan Kota Palopo. Pada tahun 2013 jumlah Kabupaten/Kota yang mampu mencapai skor efisiensi $100 \%$ menurun menjadi hanya 7 Kabupaten/Kota. Ada beberapa Kabupaten yang mengalami nilai efisiensi 100\% pada tahun 2012 tetapi mengalami penurunan pada tahun 2013 yaitu kabupaten Jeneponto, kabupaten Pangkep, kabupaten Sidrap, kabupaten Pinrang, kabupaten Enrekang dan kabupaten Toraja Utara.

- Tahun 2014, kondisi pencapain efisiensi teknis sistem belanja pendidikan menjadi 8 Kabupaten/Kota. Hanya beberapa Kabupaten/Kota yang mampu bertahan dan konsisten efisiensi 100\%. Hal ini menunjukkan bahwa secara umum belum ada upaya perbaikan efisiensi teknis sistem pada kabupaten/Kota di Provinsi Sulawesi Selatan.

Tabel 2. Nilai Efisiensi Teknis Sistem Pendidikan Per Kabupaten/Kota di Provinsi Sulawesi Selatan Tahun 2012-2014

\begin{tabular}{|l|ccc|c|}
\hline \multirow{2}{*}{ Kabupaten/Kota } & \multicolumn{3}{|c|}{ Efisiensi } & Rata-Rata \\
\cline { 2 - 4 } & $\mathbf{2 0 1 2}$ & $\mathbf{2 0 1 3}$ & $\mathbf{2 0 1 4}$ & Efisiensi \\
\hline Selayar & $100,00 \%$ & $100,00 \%$ & $100,00 \%$ & $100 \%$ \\
Bulukumba & $95.62 \%$ & $96.60 \%$ & $95.34 \%$ & $95.85 \%$ \\
Jeneponto & $88.98 \%$ & $89.71 \%$ & $88.78 \%$ & $89.16 \%$ \\
Takalar & $100,00 \%$ & $96.81 \%$ & $90.00 \%$ & $96.00 \%$ \\
Gowa & $93.93 \%$ & $94.79 \%$ & $96.42 \%$ & $95.05 \%$ \\
Sinjai & $91.70 \%$ & $91.12 \%$ & $91.99 \%$ & $91.60 \%$ \\
Maros & $96.78 \%$ & $98.14 \%$ & $98.52 \%$ & $97.81 \%$ \\
Pangkep & $98.33 \%$ & $100,00 \%$ & $100,00 \%$ & $99.44 \%$ \\
Barru & $100,00 \%$ & $98.89 \%$ & $97.54 \%$ & $99.00 \%$ \\
Bone & $98.91 \%$ & $100,00 \%$ & $98.99 \%$ & $99.30 \%$ \\
Soppeng & $94.05 \%$ & $96.70 \%$ & $95.30 \%$ & $95.35 \%$ \\
Wajo & $95.49 \%$ & $97.89 \%$ & $100,00 \%$ & $97.79 \%$ \\
Sidrap & $93.79 \%$ & $95.96 \%$ & $93.73 \%$ & $94.49 \%$ \\
Pinrang & $100,00 \%$ & $96.37 \%$ & $96.63 \%$ & $98.00 \%$ \\
Enrekang & $100,00 \%$ & $95.73 \%$ & $96.32 \%$ & $97.00 \%$ \\
Luwu & $100,00 \%$ & $99.53 \%$ & $98.57 \%$ & $99.00 \%$ \\
\cline { 2 - 3 } & $94.67 \%$ & $98.70 \%$ & $96.46 \%$ & $96.61 \%$ \\
& & & & \\
\hline & & &
\end{tabular}




\begin{tabular}{|l|ccc|c|} 
Tana Toraja & $97.16 \%$ & $100,00 \%$ & $100,00 \%$ & $99.05 \%$ \\
Luwu Utara & $99.61 \%$ & $99.52 \%$ & $98.72 \%$ & $99.28 \%$ \\
Luwu Timur & $97.61 \%$ & $96.79 \%$ & $100,00 \%$ & $98.13 \%$ \\
Toraja Utara & $100,00 \%$ & $97.20 \%$ & $96.99 \%$ & $98.00 \%$ \\
Makassar & $100,00 \%$ & $100,00 \%$ & $100,00 \%$ & $100 \%$ \\
Pare-Pare & $100,00 \%$ & $100,00 \%$ & $100,00 \%$ & $100 \%$ \\
Palopo & $100,00 \%$ & $100,00 \%$ & $100,00 \%$ & $100 \%$ \\
\hline Rata-rata Provinsi & $97.00 \%$ & $98.00 \%$ & $97.00 \%$ & \\
\hline
\end{tabular}

Sumber : Hasil Perhitungan dengan DEA-VRS-Output Orientation, diolah

\section{Efisiensi Teknis Biaya Kesehatan}

Nilai efisiensi teknis biaya kesehatan daerah Provinsi Sulawesi Selatan diperoleh dengan menggunakan input variabel berupa nominal belanja kesehatan yang dikeluarkan masing-masing daerah. Adapun variabel output yang digunakan adalah variabel output intermediate berupa indikator fasilitas dan layanan yang tersedia adalah rasio jumlah dokter per 100.000 penduduk, dan jumlah puskesmas.

Tabel 3 Nilai Efisiensi Teknis Biaya Kesehatan Per Kabupaten/Kota di Provinsi

Sulawesi Selatan Tahun 2012-2014

\begin{tabular}{|l|ccc|c|}
\hline \multirow{2}{*}{ Kabupaten/Kota } & \multicolumn{3}{|c|}{ Efisiensi } & \multirow{2}{*}{ Rata-Rata Efisiensi } \\
\cline { 2 - 4 } & $\mathbf{2 0 1 2}$ & $\mathbf{2 0 1 3}$ & $\mathbf{2 0 1 4}$ & \\
\hline Selayar & $96.08 \%$ & $75.33 \%$ & $64.45 \%$ & $78.62 \%$ \\
Bulukumba & $60.12 \%$ & $61.07 \%$ & $54.02 \%$ & $58.40 \%$ \\
Jantaeng & $74.14 \%$ & $75.15 \%$ & $72.19 \%$ & $73.83 \%$ \\
Takalar & $46.69 \%$ & $45.05 \%$ & $31.44 \%$ & $41.06 \%$ \\
Gowa & $61.70 \%$ & $56.20 \%$ & $49.27 \%$ & $55.72 \%$ \\
Sinjai & $100,00 \%$ & $100,00 \%$ & $100,00 \%$ & $100 \%$ \\
Maros & $75.82 \%$ & $72.95 \%$ & $44.54 \%$ & $64.44 \%$ \\
Pangkep & $84.05 \%$ & $63.82 \%$ & $65.68 \%$ & $71.18 \%$ \\
Barru & $69.51 \%$ & $67.64 \%$ & $60.33 \%$ & $65.83 \%$ \\
Bone & $71.07 \%$ & $74.99 \%$ & $67.77 \%$ & $71.28 \%$ \\
Soppeng & $100,00 \%$ & $100,00 \%$ & $100,00 \%$ & $100 \%$ \\
Wajo & $79.88 \%$ & $57.94 \%$ & $50.80 \%$ & $62.87 \%$ \\
Sidrap & $71.45 \%$ & $52.73 \%$ & $57.46 \%$ & $60.55 \%$ \\
Pinrang & $58.05 \%$ & $61.17 \%$ & $53.35 \%$ & $57.52 \%$ \\
Enrekang & $51.61 \%$ & $51.37 \%$ & $37.97 \%$ & $46.98 \%$ \\
Luwu & $65.57 \%$ & $54.34 \%$ & $41.78 \%$ & $53.90 \%$ \\
Tana Toraja & $60.53 \%$ & $57.57 \%$ & $42.76 \%$ & $53.62 \%$ \\
Luwu Utara & $57.72 \%$ & $54.45 \%$ & $44.71 \%$ & $52.29 \%$ \\
& $42.21 \%$ & $42.82 \%$ & $33.50 \%$ & $39.51 \%$ \\
\end{tabular}




\begin{tabular}{|l|ccc|c|} 
Luwu Timur & $38.20 \%$ & $40.74 \%$ & $34.20 \%$ & $37.71 \%$ \\
Toraja Utara & $100,00 \%$ & $100,00 \%$ & $100,00 \%$ & $100 \%$ \\
Pakassar & $100,00 \%$ & $100,00 \%$ & $100,00 \%$ & $100 \%$ \\
Palopo & $40.84 \%$ & $46.16 \%$ & $40.94 \%$ & $42.65 \%$ \\
\hline Rata-rata Provinsi & $70.62 \%$ & $66.92 \%$ & $59.36 \%$ & $87.23 \%$ \\
\hline
\end{tabular}

Sumber : Hasil Perhitungan dengan DEA-VRS-Input Orientation, diolah

Berdasarkan Tabel 3 dapat dijabarkan secara empiris hasil perhitungan dengan cara efisiensi teknis biaya kesehatan daerah Provinsi Sulawesi Selatan adalah sebagai berikut :

- Pada tahun 2012, hasil perhitungan menggunakan efisiensi teknis biaya kesehatan terdapat 4 Kabupaten/Kota yang mencapai efisiensi $100 \%$. Kabupaten Toraja Utara merupakan daerah yang mampu mencapai efisien sementara belanja kesehatannya paling rendah yaitu sebesar Rp 37.910 (milyar) jauh dibawah rata-rata keseluruhan yang mencapai Rp. 106.071 (milyar).

- Pada tahun 2013, jumlah Kabupaten/Kota yang mencapai efisiensi $100 \%$ tidak mengalami perubahan. Kabupaten Luwu Timur dan Kabupaten ParePare secara berurutan memiliki rata-rata skor efisiensi paling rendah, di mana proporsi belanja kesehatan Kabupaten tersebut jauh lebih besar dari daerah lainnya. Belanja kesehatan memiliki pengaruh yang cukup besar dalam menentukan tingkat efisiensi. Sementara daerah dengan belanja kesehatannya yang besar cenderung mengalami inefisiensi. Hal ini selaras dengan hasil penelitian yang dilakukan oleh Avonso, Schuknect dan Tanzi yang menyatakan bahwa negara dengan pengeluaran sektor publik yang lebih kecil cenderung untuk menjadi paling efisien dibanding negara yang pengeluaran sektor publiknya lebih besar.

- Sedangkan tahun 2014 kondisi pencapain efisiensi teknik biaya kesehatan hanya 4 Kabupaten/Kota yang bertahan dan konsisten mencapai efisiensi $100 \%$. Hal ini menunjukkan efisiensi secara teknis biaya kesehatan bahwa belum ada upaya perbaikan yang dilakukan oleh pemerintah daerah Provinsi Sulawesi Selatan selama periode penelitian. 


\section{Efisiensi Teknis Sistem Kesehehatan}

Tabel 4. Nilai Efisiensi Teknis Sistem Kesehatan Per Kabupaten/Kota di Provinsi Sulawesi Selatan Tahun 2012-2014

\begin{tabular}{|c|c|c|c|c|}
\hline \multirow{2}{*}{ Kabupaten/Kota } & \multicolumn{3}{|c|}{ Efsiensi } & \multirow{2}{*}{ Rata-Rata Efisiensi } \\
\hline & 2012 & 2013 & 2014 & \\
\hline Selayar & $100,00 \%$ & $100,00 \%$ & $100,00 \%$ & $100 \%$ \\
\hline Bulukumba & $99.63 \%$ & $99.28 \%$ & $97.14 \%$ & $98.68 \%$ \\
\hline Bantaeng & $100,00 \%$ & $100,00 \%$ & $100,00 \%$ & $100 \%$ \\
\hline Jeneponto & $100,00 \%$ & $97.67 \%$ & $97.67 \%$ & $98.00 \%$ \\
\hline Takalar & $99.81 \%$ & $96.75 \%$ & $96.10 \%$ & $97.55 \%$ \\
\hline Gowa & $99.85 \%$ & $95.49 \%$ & $98.32 \%$ & $97.89 \%$ \\
\hline Sinjai & $99.92 \%$ & $100,00 \%$ & $97.44 \%$ & $99.12 \%$ \\
\hline Maros & $99.78 \%$ & $97.67 \%$ & $97.15 \%$ & $98.20 \%$ \\
\hline Pangkep & $99.80 \%$ & $94.98 \%$ & $95.44 \%$ & $96.74 \%$ \\
\hline Barru & $100,00 \%$ & $97.11 \%$ & $97.00 \%$ & $98.00 \%$ \\
\hline Bone & $99.78 \%$ & $98.33 \%$ & $96.76 \%$ & $98.29 \%$ \\
\hline Soppeng & $99.71 \%$ & $95.47 \%$ & $96.68 \%$ & $97.29 \%$ \\
\hline Wajo & $99.63 \%$ & $96.58 \%$ & $94.61 \%$ & $96.94 \%$ \\
\hline Sidrap & $99.99 \%$ & $97.70 \%$ & $96.86 \%$ & $98.18 \%$ \\
\hline Pinrang & $99.93 \%$ & $96.97 \%$ & $96.70 \%$ & $97.87 \%$ \\
\hline Enrekang & $100,00 \%$ & $100,00 \%$ & $100,00 \%$ & $100 \%$ \\
\hline Luwu & $100,00 \%$ & $100,00 \%$ & $100,00 \%$ & $100 \%$ \\
\hline Tana Toraja & $99.79 \%$ & $98.18 \%$ & $100,00 \%$ & $99.32 \%$ \\
\hline Luwu Utara & $99.91 \%$ & $96.40 \%$ & $95.97 \%$ & $97.43 \%$ \\
\hline Luwu Timur & $100,00 \%$ & $94.78 \%$ & $98.34 \%$ & $98.00 \%$ \\
\hline Toraja Utara & $99,97 \%$ & $97.36 \%$ & $100,00 \%$ & $99.01 \%$ \\
\hline Makassar & $100,00 \%$ & $100,00 \%$ & $100,00 \%$ & $100 \%$ \\
\hline Pare-Pare & $100,00 \%$ & $100,00 \%$ & $100,00 \%$ & $100 \%$ \\
\hline Palopo & $99.81 \%$ & $96.72 \%$ & $99.19 \%$ & $98.57 \%$ \\
\hline Rata-rata Provinsi & $100 \%$ & $98.00 \%$ & $98.00 \%$ & \\
\hline
\end{tabular}

Sumber : Hasil Perhitungan dengan DEA-VRS-Output Orientation, diolah 
Hasil perhitungan DEA untuk efisiensi teknis sistem bidang kesehatan Provinsi Sulawesi Selatan ditunjukkan pada Tabel 4, dengan penjelasan sebagai berikut :

- Pada tahun 2012-2014 secara berturut-turut terdapat 6 Kabupaten/Kota yang mencapai efisiensi secara konsisten yaitu Kabupaten Selayar, Kabupaten Bantaeng, Kabupaten Enrekang, Kabupaten Luwu, Kota Makassar dan Kota Pare-Pare. Pencapain efisiensi 100\% ini karena kabupaten-kabupaten tersebut dengan input dokter dan jumlah puskesmas yang ada telah mampu menghasilkan output yang tinggi yaitu angka harapan hidup yang tinggi. Hal ini mempunyai makna bahwa dengan input sumber daya dan fasilitas yang ada telah mampu menekan angka kematian bayi sebagai indikator penentu derajat kesehatan yang baik.

- Sedangkan daerah Kabupaten/Kota yang belum efisien, hal ini terjadi karena input dokter dan jumlah puskesmas yang ada menghasilkan output berupa angka kematian bayi yang masih tinggi. Walaupun skor efisiensi teknis sistem sudah baik mendekati angka 100\% yang artinya rasio dokter per penduduk sudah ideal, namun daerah tersebut cukup luas misalnya Kabupaten Luwu Timur cukup luas yaitu 6.994,88 km² dan kepadatan penduduk hanya $38,79 \mathrm{jiwa} / \mathrm{km}^{2}$ sehingga hal tersebut menyulitkan tenaga dokter yang ada untuk memberikan pelayanan maksimal ke seluruh wilayah yang mengakibtkan capain outputnya menjadi rendah.

- Kondisi tersebut di atas sejalan dengan hasil penelitian darai Afonso dan Aubyn yang mengemukakan bahwa negara-negara mungkin memiliki kebutuhan input yang berbeda untuk mencapai tingkat output yang sama, tergantung pada kepadatan populasi atau tingkat perkemabangan ekonomi, bahkan dibawah pelayan publik yang efisien.

Secara keseluruhan daerah yang mencapai kondisi efisiensi ideal dalam belanja pendidikan dan kesehatan baik secara teknis biaya maupun teknis sistem belum ada daerah Kabupaten/Kota yang mencapai efisiensi sempurna $100 \%$. Dengan demikian di dalam perhitungan target perbaikan input dan output untuk seluruh Kabupaten/Kota sangat perlu perbaikan sesuai target yang harus dirubah. 
Adapun secara umum perbaikan yang dapat dilakukan terkait dengan Kabupaten/Kota yang masih belum efisien secara teknis biaya maupun teknis sistem yaitu melakukan penekanan alokasi belanja baik di sektor pendidikan dan kesehatan sehingga tidak terjadi pemborosan dan segera melakukan perbaikan, sedangkan perbaikan secara teknis sistem yaitu dengan cara meningkatkan peran guru dan dokter yang sudah ada untuk selalu menjangkau lebih banyak masyarakat yang membutuhkan layanan pendidikan dan kesehatan. Di sisi lain pemerataan jumlah fasilitas pendidikan dan kesehatan berupa sekolah dan jumlah puskesmas yang tersedia agar lebih ditingkatkan sehingga masyarakat dapat dengan mudah mengakses fasilitas pendidikan dan kesehatan dalam rangka mencapai derajat pendidikan dan kesehatan yang optimal.

\section{KESIMPULAN}

Berdasarkan hasil analisis efisiensi belanja pendidikan dan kesehatan di Provinsi Sulawesi Selatan tahun 2012-2014 dengan menggunakan metode Data Envelopment Analysis (DEA), maka dapat disimpulkan sebagai berikut :

1. Selama periode penelitian ditemukan hasil empiris bahwa secara rata-rata pemerintah Kabupaten/Kota di Provinsi Sulawesi Selatan masih mengalami inefisiensi dalam teknis biaya pendidikan dan kesehatan di masing-masing daerahnya. Fenomena ini digambarkan dengan pencapain nilai efisiensi teknis biaya untuk masing-masing Kabupaten/Kota yang secara umum masih jauh lebih sedikit dibandingkan nilai efisiensi teknis sistem. Adapun daerah yang sudah mencapai kondisi efisien selama periode penelitian untuk efisiensi teknis biaya sektor pendidikan yang konsisten maksimum 100\% adalah Kabupaten Selayar dan Kota Palopo, sedangkan daerah yang sudah mencapai skor efisiensi dalam teknis sistem adalah Kabupaten Selayar, Kota Makassar, Kota Pare-Pare dan Kota Palopo.

2. Daerah Kabupaten/Kota yang mengalami inefisiensi dalam teknis biaya pendidikan dan kesehatan mencerminkan bahwa daerah tersebut belum mampu menggunakan belanja kesehatan yang dianggarakan pemerintahnya secara optimal. Lebih lanjut, daerah yang tidak efisien dalam teknis biaya juga mengindikasikan bahwa di daerah tersebut telah terjadi pemborosan biaya belanja pendidikan dan kesehatan yang terlalu 
besar namun tidak diikuti dengan peningkatan layanan dan fasilitas pendidikan dan kesehatan dasar yang dibutuhkan masyarakat.

3. Daerah yang secara teknis sistem belum efisien berarti bahwa daerah tersebut belum mampu menggunakan input sumberdaya berupa layanan dan fasilitas pendidikan dan kesehatan dengan optimal. Temuan ini memberi arti lebih jauh bahwa dalam rangka mencapai pembagunan derajat pendidikan dan kesehatan masyarakat perlu adanya perbaikan sisitem untuk meningkatkan peran dan manfaat dari layanan dan fasilitas pendidikan dan kesehatan yang telah tersedia agar lebih efisien.

\section{DAFTAR PUSTAKA}

Afonso, Antonio dan Miguel st. Aubyn. Non-parametric Approaches to Education and Health Efficiency in OECD Countries. Journal of Applied Economics, Vol III No. 002. 2005.

Cross Country Efficiency of Secondary Education Provisnsion : A Semi Paramertic Analysis with Nondiscreationary input, 2005.

Arikunto, Suharsimi. Prosedur Penelitian Suatu Pendekatan Praktik. Jakarta : Rineka Cipta, 2002.

Basir, Muhammad Paly. Pengukuran Efisiensi dan Produktivitas Usaha Tani, Makassar : Alauddin University Press, 2011.

Boediono. Ekonomi Mikro. Yogyakarta : BPFE, 1982.

Badan Pusat Statistik Provinsi Sulawesi Selatan, 2015.

Charnes, A, WW Cooper and E Rhodes, Measuring the efficiency of Decision Maing Units. European Journal of Operational Research 2, North : Holland Publising Company, 1978.

Cooper, William, Lawrence M. Seiford and Joe Zhu. Chapter 1 : Data Envelopment Analysis : History, Model and Interpretations.

Daniel, Setyo Budi . Efisiensi Relatif Puskesmas-Puskesmas di Kabupaten Pati Tahun 2009, Tesis MPKP FE UI, 2010.

Departemen Agama RI, Al Qur'an dan Terjemahannya. Jakarta: Yaysan Al Furqan, 2008.

Dumairy. Perekonomian Indonesia, Jakarta: Erlangga, 1996.

Erniwati, dkk, Refleksi 5 Tahun Otonomi Awards. Makassar: FIPO, 2013.

Fattah, Nanang. Ekonomi dan Pembiyaan Pendidikan. Bandung: PT Remaja Rosdakarya, 2000. 
Firda, Asnita Sebayang. Kinerja Kebijakan Fiskal Daerah di Indonesia Pasca Crisis. Jurnal Fakultas Ekonomi Universitas Islam Bandung, Jurnal Ekonomi Pembangunan Vol. 10 No. 3, 2005.

Halim. Manajemen Keuangan Daerah, Yogyakarta; Edisi Revisi : BPFE, 2008.

Hasbullah, Otonomi Pendidikan : Kebijakan Otonomi Daerah dan Implikasinya Terhadap Penyelenggaraan Pendidikan. Jakarta : Rajawali Pres, 2010.

Kementrian Kesehatan Republik Indonesia, 2014

Lena, Dina Pertiwi. Efisiesi Pengeluaran Pemerintah Daerah di Provinsi Jawa Tengah. Jurnal Ekonomi Pembangunan Vol.12 No.2 : Yogyakarta, 2007.

Mardiasmo. Akuntansi Sektor Publik. Andi : Yogyakarta, 2004.

Muhmidayeli. Filsafat Pendidikan. Bandung: PT Refika Aditama, 2011.

Noor, Isran. Politik Otonomi Daerah untuk Penguatan NKRI. Kutai Kartanegara: Seven Strategic Studies, 2012.

Purwantoro, Nugroho, Efektitas Kinerja Pelabuhan dengan data Envelopment Analysis (DEA), Manajemen Usahawan Indonesia No. 05,Th XXXIII, 2004.

Qomaruddin, Saleh dkk. Asbabun Nuzul, Bandung: CV Diponegoro, 2011.

Setyo, Daniel Budi, Efisisiensi Relatif Puskesmas-Puskesmas di Kabupaten Pati Tahun 2009, Tesis MPKP FE UI, 2010.

Sudirman, Wayan. Kebijakan Fiskal dan moneter : Teori \& Empirikal. Jakarta: Kencana Prenadamedia Group, 2011.

al-Syaebani, Omar Mohammad al-Toumy. Falsafah Pendidikan Islam. Jakarta: Bulan Bintang, 1979.

Syakir Kurnia, Akhmad. Model Pengukuran Kinerja dan Efisiensi Publik M Metode Free Disposable Hull (FDH). Jurnal Ekonomi Pembangunan Vol. 11 No. 2, 2006.

Tirtarahajardja, Umar \& La Sulo. Pengantar Pendidikan. Jakarta: PT Rineka Cipta, 2015.

Undang-Undang RI No 32 Tahun 2004 Tentang Pemerintahan Daerah

Undang-Undang RI No 23 Tahun 1992 Tentang Kesehatan

Undang-Undang Otonomi Daerah. Jakarta : Pustaka Pergaulan, 2004.

Wijaya, HAW. Penyelenggaraan Otonomi di Indonesia. Jakarta: PT Raja Grafindo Persada, 2005.

Yani, Ahmad. Hubungan Keuangan antara Pemerintah Pusat dan Daerah di Indonesia. Jakarta: Rajawali Pers, 2009.

Zainal, Yasman Basri dan Subri Mulyadi. Keuangan Negara dan Analisis Kebijakan Utang Luar Negeri, Jakarta: PT Raja Grafindo, 2009. 


\section{E C C E S}

Economics, Social, and evelopment Studies

Jurusan IImu Ekonomi

Fakultas Ekonomi dan Bisnis Islam UIN Alauddin

Kampus II Jl. SIt Alauddin No.36 Samata Sungguminasa-Gowa Telp (424835)

Email: ecces@uin-alauddin.ac.id

Aturan penulisan Jurnal IImu Ekonomi Fakultas Ekonomi dan Bisnis Islam UIN Alauddin Makassar adalah sebagai berikut:

1. Artikel harus berupa tulisan asli, merupakan hasil penelitian maupun kajian dalam bidang ekonomi terapan dan belum pernah dipublikasikan di media manapun serta bebas dari unsur-unsur plagiarisme.

2. Artikel ditulis dalam Bahasa Indonesia dengan memenuhi kaidah EYD Bahasa Indonesia.

3. Sistematika penulisan:

a. Bagian awal: judul, nama penulis (dituliskan lengkap tanpa gelar), abstrak yang tidak lebih dari 300 kata dan diketik dengan satu spasi yang berisi latar belakang, tujuan, metodologi, dan hasil penelitian.

b. Bagian utama: pendahuluan, tinjauan teoritis dan pustaka, metode penelitian, hasil dan pembahasan, serta kesimpulan.

c. Bagian akhir: daftar pustaka, dan lampiran.

4. Judul artikel ditulis dengan menggunakan huruf kapital.

5. Teknik penulisan:

a. Alinea baru dimulai pada ketikan kelima pada batas tepi kiri. Antar alinea tidak diberi tambahan spasi.

b. Penggunaan kata asing ditulis dengan menggunakan huruf miring (italic).

c. Batas pengetikan: tepi kiri tiga $\mathrm{cm}$, tepi kanan dua $\mathrm{cm}$, tepi atas tiga $\mathrm{cm}$, dan tepi bawah dua $\mathrm{cm}$.

d. Tabel, gambar, dan ilustrasi lainnya diberikan judul, nomor, dan sumber yang jelas.

e. Sumber pustaka ditulis nama-tahun (nama belakang penulis, tahun penerbitan). Nama penulis harus tepat sama dengan yang tercantum dalam daftar pustaka.

6. Naskah diketik dengan MS Word, spasi satu, ukuran font 11, huruf Arial, dengan panjang minimum-maksimum 15-20 halaman (A4).

7. Tulisan harus dikirim paling lambat 1 bulan sebelum penerbitan jurnal ke email jurnal Ecces atau diserahkan langsung ke tim pengelola dalam bentuk CD.

8. Jurnal Ecces terbit 2 kali dalam setahun, yaitu Juni dan Desember.

9. Email jurnal Ecces: jurnalecces@gmail.com 


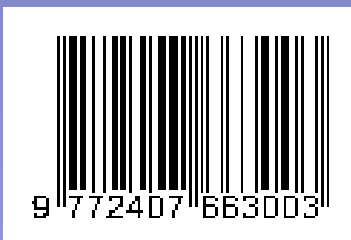

